\title{
Pharmacokinetic parameters of meloxicam after its oral administration in goat
}

\author{
A. R. Wani, S. U. Nabi, S. A. Bhat, O. S. Shah, N. A. Kutchy and R. K. Roy
}

Department of Pharmacology and Toxicology,

College of Veterinary Science, Assam Agricultural University, Khanapara Campus, Guwahati-781022, India.

Corresponding author: Abdul Rakeeb Wani, Present address: Friends Enclave, Near SSM College, Bagat Barzulla, Srinagar, J \& K. Mobile no: +91-9906958601.email: etheralecho@gmail.com

Received: 28-01-2014, Revised: 10-02-2014, Accepted: 12-02-2014, Published online: 12-03-2014

doi: 10.14202 /vetworld.2014.141-145

How to cite this article: Wani AR, Nabi SU, Bhat SA, Shah OS, Kutchy NA and Roy RK (2014) Pharmacokinetic parameters of meloxicam after its oral administration in goat, Veterinary World 7(3): 141-145.

\begin{abstract}
Aim: The objective of the present study was to find out the levels of analgesic drug meloxicam in the blood plasma of young goats. The drug was given to them through oral route. Data was used to elucidate the Pharmacokinetic determinants of the drug which were employed to arrive at the dose schedule and frequency of the drug in goats.

Materials and Methods: Elaborate pharmacokinetic research of the drug meloxicam was done on 18 to 24 months old, five adult male local goats (Capra hircus) of Assam weighing 20 to $25 \mathrm{~kg}$. The drug was given orally at the dose rate of $0.35 \mathrm{mg} / \mathrm{kg}$ at the Goat Rearing farm, Guwahati, Assam. Analysis of blood was done by high performance liquid chromatography (HPLC) system.

Results: The mean values of area under curve (AUC) and mean area under curve (AUMC) were $3137.488 \pm 125.3749$ $\mu \mathrm{g} . \mathrm{min} / \mathrm{ml}$ and $4650460 \pm 380892.4744 \mu \mathrm{g} . \mathrm{min}^{2} / \mathrm{ml}$ respectively .The mean peak plasma level of meloxicam was $1.972 \pm$ $0.0477 \mu \mathrm{g} / \mathrm{ml}$ at $600 \mathrm{~min}$. The mean values of elimination half life $\left(\mathrm{t}_{1 / 2 \beta}\right)$ and absorption half life $\left(\mathrm{t}_{1 / 2 \mathrm{Ka}}\right)$ were $693 \pm 0.00 \mathrm{~min}$ and $170.6 \pm 17.0076 \mathrm{~min}$ respectively. The mean values of volume of distribution $(\mathrm{Vd})$ and mean residence time (MRT) were 0.114 $\pm 0.0156 \mathrm{~L} / \mathrm{kg}$ and $1472.264 \pm 63.336 \mathrm{~min}$ respectively. The mean value of $\mathrm{T}_{\max }$ was found to be $497 \pm 19.8040 \mathrm{~min}$. Following single oral administration the minimum effective therapeutic concentration or minimum effective plasma concentration of meloxicam was detectable up to $1200 \mathrm{~min}$. The bioavailibity (F) of the drug was $80.5 \pm 10.0150 \%$.
\end{abstract}

Conclusion: These pharmacokinetic determinants were used to determine the frequency and dose schedule of meloxicam in goats. The minimum effective concentration of the drug is $0.7 \mu \mathrm{g} / \mathrm{ml}$ in plasma. To maintain this, an initial loading dose of 0.5 $\mathrm{mg} / \mathrm{kg}$ body weight should be followed by a maintenance dose of $0.4 \mathrm{mg} / \mathrm{kg}$ body weight $/ 10$ hour.

Keywords: half-life, male Assam goat, meloxicam, oral administration.

\section{I ntroduction}

Meloxicam is a potent anti-inflammatory agent, being a relatively selective Cox-2 inhibitor [1], in comparison to older non-steroidal anti inflammatory drugs (NSAIDs) which none selectively also inhibit Cox-1 isoenzyme, leading to serious gastrointestinal and renal side effects. Meloxicam is 12 times more selective in inhibiting Cox- 2 activity than Cox-1 activity $[2,3]$. The higher selectivity results in low ulcerogenic potential and less gastrointestinal irritation as compared to other NSAIDs $[4,5]$. This less toxicity of the drug makes it a broad spectrum drug covering a varying number of diseases. In conjunction with a suitable antibiotic, it is used as a drug of choice in many diseases [4,5]. Meloxicam prevents ongoing occurrence of inflammation by inhibiting prostaglandin production, that sensitize the afferent nociceptors at peripheral sites of inflammation [6,7].

In man it is used for treating non descriptive pyrexia, painful conditions due to acute and chronic

Copyright: The authors. This article is an open access article licensed under the terms of the Creative Commons Attribution License (http://creativecommons.org/licenses/by/2.0) which permits unrestricted use, distribution and reproduction in any medium, provided the work is properly cited. inflammation, muscular pain, joint pain, rheumatic pain, neuralgia, soft tissue injuries and immobility associated with lameness, arthritis and myositis $[1,4$, 5]. In veterinary practice Meloxicam was introduced for management of canine osteoarthritis and since then it is being used for the management of pain and inflammation, arising from both acute and chronic conditions $[3,7,8]$. In cattle it is used to treat pain, mastitis, pneumonia and other inflammatory conditions $[9,10]$. Indications for meloxicam use in farm animals include respiratory infections and acute mastitis [11]. It is being increasingly used in manage-ment of musculoskeletal disorders for reduction in pain and inflammation [12].

Pharmacokinetic profile of meloxicam has been elucidated in human beings [1,4], cattle [10,11], sheep and goat [13,14], rabbit [15], vulture [16], horses [17], camels [18], piglets [19], green iguanas [20], cats [21], llamas [22] and many other species of animals.. But data of one species cannot be extrapolated and used in other species due to high interspecies variation in the metabolism of meloxicam. Interspecies variation along with local and regional factors further compound the problem. Goat is called as poor man's cow owing to its utility and popularity among the farmers of India. Also 


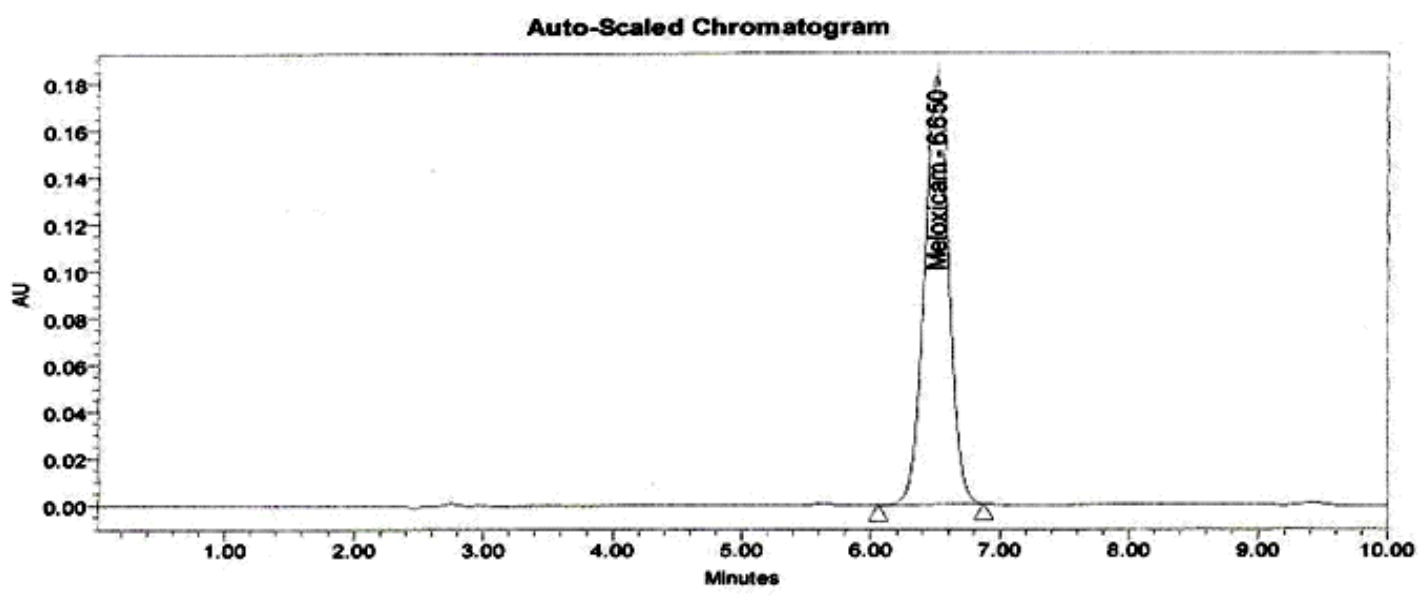

Figure-1. Plasma concentration of Meloxicam in HPLC data system after oral administration

much information is not available on the pharmacokinetic profile of this drug in small ruminants. Hence the present study was conducted to determine the complete pharmacokinetics, dosing schedule and dosing frequency of this drug after its oral administration in the domestic goat of Assam.

\section{Materials and Methods}

Experimental animals: Experimental animals were 20 to 24 months old, five male goats (Capra hircus) of Assam, with body weight ranging between 20 to $25 \mathrm{~kg}$. Clinically all the animals were sound and healthy and were raised at Goat rearing farm, Guwahati, Assam.

Ethical approval: Adherence to all the concerned ethical principles as enumerated by the International Animal Ethics Committee, was observed strictly throughout the course of this study. Animals were handled gently and carefully. Deworming was done one month before the start of experimentation with the help of fenbendazole which was given at the rate $1 \mathrm{ml} / \mathrm{kg}$ body weight.

Instruments used: High performance liquid chromatography (HPLC) system. Waters HPLC system consisting of a Degasser, two pumps A and B (Waters 515 HPLC pump), an injector, C-18 symmetry column (particle size $5 \mu \mathrm{m} ; 4.6 \mathrm{~mm}$ x $250 \mathrm{~mm}$ ), Waters 2487 dual $\lambda$ absorbance detector and a screen was used. (Waters Breeze Software, Ireland). Centrifuge machine (Labnet). Two micropipettes $100 \mu \mathrm{l}$ (fixed) and 2-20 $\mu \mathrm{l}$ (adjustable).Vortex mixer cum shaker. BD Vacuntainer (sodium Heparin $[\mathrm{NH}] 68$ USP units plus blood collection tubes, $5 \mathrm{ml}$ ). Tarpons $1.5 \mathrm{ml}$ micro-centrifuge tubes. $0.22 \mu \mathrm{m}$ nylon filter. Test tubes, Flasks, measuring cylinders, spirit, cotton, scissors. Syringes $(2 \mathrm{ml}$ and 5 $\mathrm{ml})$.

Drugs and chemicals used: Pure standard Meloxicam (Meloxicam oral suspension BP vet, $1.5 \mathrm{mg} / \mathrm{ml}$, Meloxicam i.v solution $5 \mathrm{mg} / \mathrm{ml}$ ). HPLC grade Acetonitrile and HPLC grade water.

Estimation of meloxicam: A single dose of meloxicam was administered orally into the animals at the rate of $0.35 \mathrm{mg} / \mathrm{kg}$ as per their body weights. Blood samples ( 5 $\mathrm{ml}$ ) were collected from jugular vein with the help of a
$5 \mathrm{ml}$ syringe from all the goats, into vacuntainer heparinized tubes before and after the drug administration. Blood was collected at 30, 45, 60, 120, 180, 240, 360, $480,540,600,720,840,1440$ and 2880 minutes respectively. Blood samples were centrifuged at 3600 rpm for 12 minutes and the plasma thus extracted was stored in $1.5 \mathrm{ml}$ capped micro-centrifuge tubes in a refrigerator at $-5^{\circ} \mathrm{C}$ till further processing which was done within 5 days of plasma collection. The drug was quantitatively estimated from the plasma of animals by advanced Baert and De Backers HPLC method [23]. Mobile phase used for chromatography was a mixture of $65 \%$ water: acetic acid $(99: 1, \mathrm{v} / \mathrm{v})$ and $35 \%$ acetonitrile with a flow rate of $0.8 \mathrm{ml} / \mathrm{min}$. Drug detection was done at $355 \mathrm{~nm}$ wavelength. Column temperature of the oven was $35^{\circ} \mathrm{C}$ and drugs retention time was 6.65 min.

Chemical assay of meloxicam: The above collected plasma was used for the analysis of the drug. $0.5 \mathrm{ml}$ of plasma was mixed with $0.5 \mathrm{ml}$ of acetonitrile. Vortex Mixer was used to mix the two and the mixture was then centrifuged for 20 minutes at $6200 \mathrm{rpm}$. Clear supernatant was collected and $0.5 \mathrm{ml}$ of HPLC grade water was added to it. The aliquot thus obtained was filtered through $0.22 \mu \mathrm{m}$ nylon filter paper. $20 \mu \mathrm{l}$ of this filtrate was introduced into HPLC system.

Preparation of standard curve: Drug free plasma was spiked with the standard meloxicam at a concentration of $0.5,1.0,1.75,2.5,5.0,7.5,10.0,15.0$ and $20.0 \mu \mathrm{g} / \mathrm{ml}$ of plasma and then plasma standards were prepared. Quantification of drug was done from its respective peak area and calibration curves were employed to determine the concentration of drug in plasma samples. Determination of meloxicam concentration in a representative sample of goat is depicted in Figure-1.

Pharmacokinetic analysis of data: Log of plasma drug concentration versus time profile was employed to arrive at pharmacological determinants of every animal by Gibaldis "two compartment open model" [24]. Mean and SE for each determinant was obtained from the whole data. Standard statistical method was employed for statistical interpretation [25]. 
Table-1. Plasma concentrations $(\mu \mathrm{g} / \mathrm{ml})$ of meloxicam in goat after oral administration at the dose rate of $0.35 \mathrm{mg} / \mathrm{kg}$ body weight.

\begin{tabular}{|c|c|c|c|c|c|c|}
\hline \multirow[t]{2}{*}{ Time(minutes) } & \multicolumn{5}{|c|}{ Animals $(n=5)$} & \multirow[t]{2}{*}{ Mean \pm SE } \\
\hline & 1 & 2 & 3 & 4 & 5 & \\
\hline 30 & 0.40 & 0.33 & 0.46 & 0.51 & 0.49 & $0.438 \pm 0.0327$ \\
\hline 45 & 0.48 & 0.41 & 0.53 & 0.62 & 0.58 & $0.524 \pm 0.0369$ \\
\hline 60 & 0.66 & 0.59 & 0.61 & 0.69 & 0.66 & $0.642 \pm 0.0215$ \\
\hline 120 & 0.70 & 0.69 & 0.67 & 0.71 & 0.70 & $0.691 \pm 0.0212$ \\
\hline 180 & 0.98 & 0.93 & 0.89 & 0.96 & 0.94 & $0.94 \pm 0.0151$ \\
\hline 240 & 1.40 & 1.21 & 1.28 & 1.38 & 1.42 & $1.338 \pm 0.0401$ \\
\hline 360 & 1.68 & 1.45 & 1.52 & 1.64 & 1.71 & $1.6 \pm 0.0494$ \\
\hline 480 & 1.94 & 1.88 & 1.87 & 1.72 & 2.18 & $1.918 \pm 0.0748$ \\
\hline 540 & 1.99 & 2.01 & 1.94 & 1.79 & 2.02 & $1.95 \pm 0.0423$ \\
\hline 600 & 2.10 & 2.04 & 1.99 & 1.84 & 1.89 & $1.972 \pm 0.0476$ \\
\hline 720 & 1.60 & 1.72 & 1.78 & 1.58 & 1.64 & $1.664 \pm 0.0376$ \\
\hline 840 & 1.28 & 1.24 & 1.36 & 1.30 & 1.39 & $1.314 \pm 0.0271$ \\
\hline 1440 & 0.70 & 0.69 & 0.67 & 0.74 & 0.72 & $0.684 \pm 0.0354$ \\
\hline 2880 & 0.34 & 0.31 & 0.38 & 0.24 & 0.40 & $0.3314 \pm 0.0271$ \\
\hline
\end{tabular}

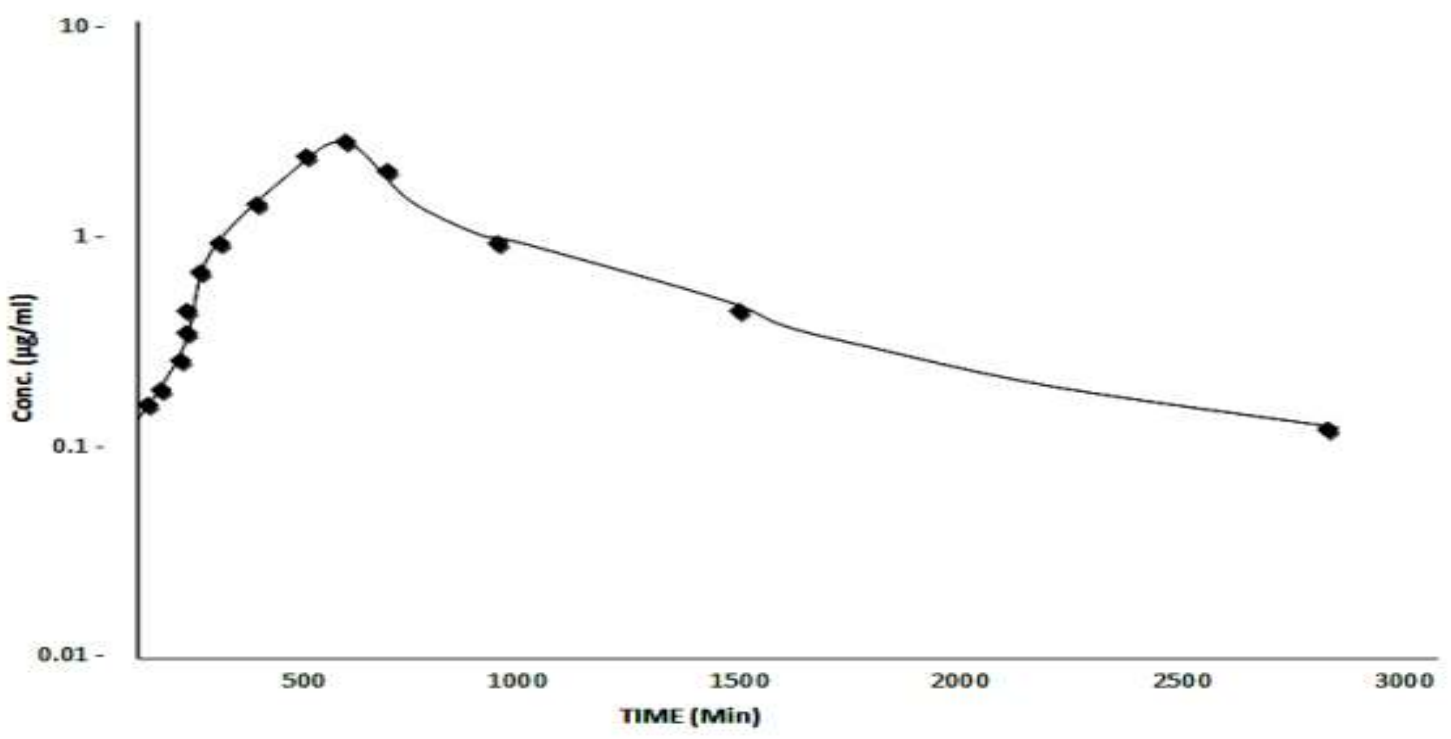

Figure-2. Mean plasma values of Meloxicam in goat after oral administration at the dose rate of $0.35 \mathrm{mg} / \mathrm{kg}$.

Table-2. Pharmacokinetics of Meloxicam after single oral administration at the dose rate of $0.35 \mathrm{mg} / \mathrm{kg}$ in goat. ( $n=5)$

\begin{tabular}{|c|c|c|c|c|c|c|c|}
\hline \multirow[t]{2}{*}{ Time(minutes) } & \multirow[t]{2}{*}{ Units } & \multicolumn{5}{|c|}{ Animals $(n=5)$} & \multirow[t]{2}{*}{ Mean \pm SE } \\
\hline & & 1 & 2 & 3 & 4 & 5 & \\
\hline$A$ & $\mu \mathrm{g} / \mathrm{ml}$ & 3.93 & 2.80 & 2.60 & 2.77 & 2.77 & $2.974 \pm 0.2415$ \\
\hline B & $\mu \mathrm{g} / \mathrm{ml}$ & 4.04 & 2.88 & 2.74 & 2.8 & 2.77 & $3.046 \pm 0.2495$ \\
\hline $\mathrm{Ka}$ & $\min ^{-1}$ & 0.003 & 0.004 & 0.004 & 0.005 & 0.005 & $0.0042 \pm 0.0003$ \\
\hline $\mathrm{t} 1 / 2 \mathrm{Ka}$ & $\min$ & 231 & 173 & 173 & 138 & 138 & $170.6 \pm 17.0076$ \\
\hline$\beta$ & $\min ^{-1}$ & 0.001 & 0.001 & 0.001 & 0.001 & 0.001 & $0.001 \pm 0.00$ \\
\hline $\mathrm{t} 1 / 2 \beta$ & $\min$ & 693 & 693 & 693 & 693 & 693 & $693 \pm 0.00$ \\
\hline Vd & $\mathrm{Lit} / \mathrm{kg}$ & 0.09 & 0.12 & 0.12 & 0.12 & 0.12 & $0.114 \pm 0.156$ \\
\hline $\mathrm{F}$ & $\%$ & 61.5 & 109 & 70 & 100 & 62 & $80.5 \pm 10.0149$ \\
\hline AUC & $\mu \mathrm{g} \cdot \min / \mathrm{ml}$ & 3019.55 & 3075.34 & 3342.8 & 2768.41 & 3481.34 & $3137.488 \pm 125$ \\
\hline AUMC & $\mu \mathrm{g} . \min 2 / \mathrm{ml}$ & 4167907 & 4478290 & 5373214 & 3588243 & 5644645 & $4650460 \pm 380892$ \\
\hline Cmax & $\mu \mathrm{g} / \mathrm{ml}$ & 1.70 & 1.50 & 1.55 & 1.60 & 1.69 & $1.608 \pm 0.0389$ \\
\hline Tmax & $\min$ & 522 & 528 & 528 & 426 & 481 & $497 \pm 19.8041$ \\
\hline MRT & $\min$ & 1380.30 & 1456.19 & 1607.30 & 1296.13 & 1621.4 & $1472.264 \pm 63.3305$ \\
\hline $\mathrm{Clb}$ & $\mathrm{L} / \mathrm{min} / \mathrm{kg}$ & 0.0001 & 0.0001 & 0.0001 & 0.0001 & 0.0001 & $0.0001 \pm 0.00$ \\
\hline Kel & $\min ^{-1}$ & 0.0026 & 0.0018 & 0.0015 & 0.002 & 0.0015 & $0.00188 \pm 0.0002$ \\
\hline $\mathrm{K} 21$ & $\min -^{-1}$ & 0.002 & 0.0025 & 0.0025 & 0.003 & 0.003 & $0.0026 \pm 0.00018$ \\
\hline K12 & $\min ^{-1}$ & 0.0006 & 0.0007 & 0.001 & 0.001 & 0.0015 & $0.00096 \pm 0.00015$ \\
\hline
\end{tabular}

\section{Results}

Amount of the drug present in the plasma samples of the goats at different time periods was used to elucidate different pharmacokinetic determinants. Magnitude of drug at varying times in the plasma of goats after its single oral administration has been presented in Table-1.

Mean peak plasma level of drug was $1.972 \pm 0.047$ $\mu \mathrm{g} / \mathrm{ml}$ at $600 \mathrm{~min}$, which decreased quickly to $1.314 \pm$ $0.0271 \mu \mathrm{g} / \mathrm{ml}$ at $840 \mathrm{~min}$ of time. From this time onwards the decrease is uniform and the smallest concentration of about $0.3314 \pm 0.0271 \mu \mathrm{g} / \mathrm{ml}$ was detected at 2880 
min. This decrease of drug with respect time in goat plasma has been depicted in Figure-2.

This quantification of meloxicam in plasma samples of goat was used to arrive at different pharmacokinetic determinants which have been presented in Table- 2 .

The value of elimination half-life $\left(\mathrm{t}_{1 / 2 \beta}\right)$ was $693 \pm$ $0.00 \mathrm{~min}$. The value of mean absorption half life $\left(\mathrm{t}_{1 / 2 \mathrm{Ka}}\right)$ was $170.6 \pm 17.0076 \mathrm{~min}$. The mean values of $\mathrm{T}_{\text {max }}$ and bioavailibity $(\mathrm{F})$ were found to be $497 \pm 19.8041 \mathrm{~min}$ and $80.5 \pm 10.01498 \%$ respectively. $0.7 \mu \mathrm{g} / \mathrm{ml}$ of plasma is the minimum effective therapeutic concentration of drug and it was present up to 1200 min after a single oral administration. The mean values of AUC and AUMC were $3137.488 \pm 125.3749 \mu \mathrm{g} / \mathrm{min} / \mathrm{ml}$ and $4650460 \pm 380892.4744 \mu \mathrm{g} . \mathrm{min}^{2} / \mathrm{ml}$ respectively. Mean value of volume of distribution $(\mathrm{Vd})$ was $0.114 \pm 0.156$ $\mathrm{L} / \mathrm{kg}$. Mean residence time (MRT) of the drug was found to be $1472.264 \pm 63.3305 \mathrm{~min}$.

\section{Discussion}

In the present study, meloxicam was administered orally at a dose rate of $0.35 \mathrm{mg} / \mathrm{kg}$ of body weight in goats. Similar dose rate in the range of 0.2 to $0.6 \mathrm{mg} / \mathrm{kg}$ of body weight were used in horses [17], rabbits [15] and Vultures [16]. The mean peak plasma level of meloxicam was $1.972 \pm 0.0476$ at $600 \mathrm{~min}$, which declined rapidly to $1.314 \pm 0.0271 \mu \mathrm{g} / \mathrm{ml}$ at $840 \mathrm{~min}$ of time, thereafter the decline was steady and the lowest concentration of $0.334 \pm 0.0282 \mu \mathrm{g} / \mathrm{ml}$ was observed at $2880 \mathrm{~min}$.

The time to achieve maximum plasma concentration $\left(T_{\max }\right)$ was found to be $497 \pm 19.8040$ min which was less than that observed in calves $[9,10]$ but was more than dogs (450 min) [26,27] and rabbits (360 min) [15]. This implies that the peak drug concentration is achieved rapidly in the plasma of goats in comparison to cattle.

The value of bioavailibity (F) was found to be $80.5 \pm 10.0150 \%$ in the present study. This is less than that found in cattle $(100 \%)$ and horses $(98 \%)[10,17]$. This low bioavailability of meloxicam in goats indicates that the drug is available less adequately to systemic circulation after its oral administration. This may be due to ion trapping effect as the drug is acidic in nature or due to its quicker biotransformation [13]. The value of mean absorption half life $\left(\mathrm{t}_{1 / 2 \mathrm{Ka}}\right)$ was found to be $170.6 \pm 17.0076 \mathrm{~min}$ indicating good absorption rate of the drug after oral administration.

The value of mean elimination half-life $\left(t_{1 / 2 \beta}\right)$ was $693 \pm 0.00 \mathrm{~min}$ which was less than in cattle $(1600 \mathrm{~min})$ $[10,11]$ but comparable to that of horses $(510 \mathrm{~min})$ [16] and rabbits $(480 \mathrm{~min})$ [15]. This reflects an overall enhanced persistence of meloxicam in the plasma of goats and points to the fact that meloxicam is excreted quickly in goats in comparison to other species [28]. This is in accordance to the finding that hepatic tissue of goats possesses higher concentration of drug degrading enzymes than sheep [29] and cattle [10].

The mean residence time (MRT) observed in the present study was $1472.264 \pm 63.3305$ min which is significantly lower than in cattle $(2700 \mathrm{~min})[9,10]$, again indicating that the drug is excreted quickly in goats than in cattle. This is supported by the fact that meloxicam has a bit more tissue binding in cattle than in goat [4]. The values of AUC and AUMC obtained after oral administration of $0.35 \mathrm{mg} / \mathrm{kg}$ body weight were $3137.488 \pm 125.3749 \mu \mathrm{g} / \mathrm{min} / \mathrm{ml}$ and $4650460 \pm$ $380892.4744 \mu \mathrm{g} / \mathrm{min}^{2} / \mathrm{ml}$ respectively. The mean value of volume of distribution (Vd) was $0.114 \pm 0.156 \mathrm{~L} / \mathrm{kg}$ which is less than cattle $(0.242 \mathrm{~L} / \mathrm{kg})$ [10]. This indicates that the meloxicam is well distributed in cattle than in goats when given orally.

\section{Conclusion}

As per the interpretation of results, data follows a first order rate kinetics fitting into a two compartmental open model as do many other NSAIDS. When given orally the bioavailability of the drug was better because of its better dissolution and absorption. Effective concentration of the drug was present upto 20 hours in the blood plasma. Following oral administration of meloxicam, an initial loading dose of $0.5 \mathrm{mg} / \mathrm{kg}$ body weight succeeded by a maintenance dose of $0.4 \mathrm{mg} / \mathrm{kg}$ body weight $/ 10$ hours is advised to maintain its effective concentration. The elimination of the drug was slow and the mean value of volume of distribution (Vd) was lesser after oral administration which indicates that the overall absorption and distribution of the drug after oral administration was very slow when compared to intravenous route of administration. Mean residence time is more than double after oral administration than after IV administration

\section{Authors' contributions}

Implementation of study design, experimentation and data recording was done by ARW and RKR. SUN, OSS, SAB and NAK carried out analysis. ARW drafted and revised the manuscript. All the authors read and approved the final manuscript.

\section{Acknowledgements}

The authors are thankful to Goat rearing farm, Guwahati, Assam and Drug analyzing laboratory, Assam for help. Department of Veterinary pharmacology and toxicology of Assam agriculture university funded the research program.

\section{Competing interests}

The authors declare that they have no competing interests.

\section{References}

1. Mirinda, L.C. and David, R.W (2010) A case study of meloxicam. J. Pharmac. Sci., 100: 2172-2181.

2. Kay, M, P., Benn, S. J., LaMarre J. and Conlon, P. (2000) In vitro effects of nonsteroidal anti-inflammatory drugs on cyclooxygenase activity in dogs. Am. J. Vet. Res., 7, 802-810.

3. Innes, J., Neil, O.T. and Lascelles, D. (2010) Use of non steroidal anti-inflammatory drugs for the treatment of canine osteoarthritis. J. Brit. Vet. Assoc.28:139-44.

4. Engelhardt, G., Homma, D., Schlegel, K., Schnitzler, C., and Utzmann, R., (1996) General pharmacology of Meloxicam. 
Part 1.Gen. Pharmacol.; 51:29-38.

5. Sweetman, S. C. (Ed) (2005) Martindale; The complete drug reference: 34th edn., Pharmaceutical press, London., p. 56.

6. Lascelles, B. D. X., Henderson, A. J. and Hackett, I. J. (2001) Evaluation of the clinical efficacy of meloxicam in cats with painful locomotor disorders. J. Small Anim. Pract. 42: 587-593.

7. Doig, P. A., Purbrick, K. A., Hare, J. E. and Mekeown, D. B. (2000) Clinical efficacy and tolerance of meloxicam in dogs with chronic osteoarthritis. Can. Vet. J., 41, 296-300.

8. Joubert, K. E, (2009). The effect of Firocoxib (an NSAID) in geriatric dogs over a period of 90 days. J. S. Afr. Vet. Assoc. 80: 67-69.

9. Johnn, F.C., Ruby, A.M. and Laura, E.K. (2011) Pharmacokinetics of gabapenti alone or co-administered with meloxicam in ruminant beef calves. Vet. J., 190: 98-102.

10. Coetzee, J.F., Butch, K.M., and Allen, P.S., (20 07). Pharmacokinetics of intravenous and oral Meloxicam in ruminant calves. Vet Therapeut;10 (4): 67-71.

11. Alassane, K., Pagot, E., Armelle, P. and Guidarine, C. (2010) Pre-emptive Meloxicam for post-operative analgesia in piglets undergoing surgical castration. Vet Anaesth Analg.; 37(4):367-74.

12. Coetzee, J.F., Thompson, M.K. and Huber, C. (2012) Pharmacokinetics and effect of intravenous Meloxicam in weaned Holstein calves following scoop dehorning without anaesthesia. BMC Vet. Res.: 8: 153.

13. Shukla, W.L., Singh, G., Sindhura, B.G., Telang, .G., Rao, G.S., and Malik, J.K. (2007) Comparative plasma pharmacokinetics of Meloxicam in sheep and goats following intravenous administration. Comp. Biochem. Physiol C Toxicol Pharmacol.145: 528-32.

14. Busch.U. (1994) The pharmacokinetics of Meloxicam in animals. Scand. J. Rheumatol.19: 119.

15. Turner, P.V., and Taylor, W.M. (2006). Pharmacokinetics of Meloxicam in rabbits after single and repeat oral dosing. Comp.Med:56: 63-67.

16. Naidoo, V., Wolter, K., Cramarty, A. D., and Bartels, P., (2008) The pharmacokinetics of Meloxicam in vultures. $J$. Vet. Pharmacol Therapeut.31(2);128-134

17. Lees, P., Sedgwick, A.D., Higgins, A.J., Pugh, K.E. and Busch, U. (1991) Pharmacokinetics and pharmacodynamics of Meloxicam in horse. Br. Vet. J: 147: 97-108.

18. Wasfi, I.A., Al Ali, W.A. and Agha, B.A. (2012) The Pharmacokinetics and Metabolism of Meloxicam in Camels after intravenous administration. J. Vet. Pharmacol. Therapeut. 35(2): 155-62.

19. Fosse, T.K. and Spadavecchia, C. (2011). Pharmacokinetic and Pharmacodynamic effects of Meloxicam in piglets subjected to a Kaolin inflammation model. J. Vet. Pharmacol. Therapeut. 34(4): 367-75.

20. Stephen, J., Peats, G.K., Murphy, D.J., and Stuwart, M. (2010) Pharmacokinetics of Meloxicam following intravenous and oral administration in green iguanas. Am. J. Vet. Res. 100:147-54.

21. Lehr, T., Arbe, R.N., Jons, O., Kloft, C. and Taab, A.S. (2010) Population pharmacokinetic modeling and simulation of single and multiple dose administration of Meloxicam in cats. J. Vet. Pharmacol. Therapeut. 33(3): 277-86.

22. Amanda, J.K., Luther, J., William, G.L. and Walter, L.K. (2012) Bioavailability and pharmacokinetics of Meloxicam in llamas. BMC Vet. Res. 79: 83.

23. Baert, K. and Backer, P. (2003) Comparative pharmacokinetics of three non steroidal anti-inflammatory drugs in five bird species. Comp. Biochem. Physiol. Part C: 134: 25-33.

24. Gibaldi, M. and Perrier, D. (1982). Pharmacokinetics. $2^{\text {nd }}$ edition. Marcel-Decker Inc., New York. pp. 677-789.

25. Snedecor, G.W and Cochran, W.G. (1994). Statistical Methods. $8^{\text {th }}$ edn. Iowa State University Press, Ames, Iowa, USA-50010.

26. Hare, J.E., Niemuller, C.A. and Petrick, D.M. (2012) Target animal safety study of Meloxicam administered via transmucosal oral spray for 6 months in dogs. J. Vet. Pharmacol. Therapeut.36(4):412-6.

27. Patricia, D. (2000). Antimicrobial therapy for small animal practitioners. Acad. Vet. Med. 1: 1-20.

28. Ingvast, C., Hogberg, M., Mengistu, U., Oslsen, C. (2011) Pharmacokinetics of Meloxicam in adult goats and its analgesic effect in disbudded kids. J. Vet. Pharmacol. Therapeut. 34 (1): 64-69.

29. Wesongah, J.O., Jones, T.W. and Murilla, G.A. (2004) A comparative study of isometamidium chloride in sheep and goats. Small Rumin. Res., 53: 9-14. 